\section{Comparing food environment and food purchase in areas with low and high prevalence of obesity: data from a mapping, in-store audit, and population-based survey}

\author{
Uma comparação do ambiente alimentar e \\ da compra de alimentos entre áreas com \\ prevalência de obesidade baixa e alta: dados \\ de mapeamento, auditoria de lojas hortifruti e \\ inquérito populacional
}

\section{Comparando entornos alimentarios y adquisición de alimentos en áreas con baja y alta prevalencia de obesidad: datos procedentes de un mapeo, auditoría en tiendas y encuesta de base poblacional}

\begin{abstract}
Our study aimed to compare key aspects of the food environment in two lowincome areas in the city of Campinas, São Paulo State, Brazil: one with low and the other with high prevalence of obesity. We compared the availability of retail food establishments, the types of food sold, and the residents' eating habits. Demographic and socioeconomic data and eating habits were obtained from a population-based health survey. We also analyzed local food environment data collected from remote mapping of the retail food establishments and audit of the foods sold. For comparison purposes, the areas were selected according to obesity prevalence (body mass index $-B M I \geq 30 \mathrm{~kg} / \mathrm{m}^{2}$ ), defined as low prevalence $(<25 \%)$ and high prevalence ( $>45 \%)$. Only 18 out of the 150 points of sale for food products sold fruits and vegetables across the areas. Areas with high obesity prevalence had more grocery stores and shops specialized in fruits and vegetables, as well as more supermarkets that sold fruits and vegetables. With less schooling, residents in the areas with high obesity prevalence reported purchasing food more often in supermarket chains and specialized shops with fruits and vegetables, although they consumed more sodas when compared with residents of areas with low obesity prevalence. Our results suggest interventions in low-income areas should consider the diverse environmental contexts and the interaction between schooling and food purchase behaviors in settings less prone to healthy eating.
\end{abstract}

Obesity; Environment and Public Health; Feeding Behavior; Food
Daniele Flaviane Mendes Camargo 1

Ana Paula Belon 2

Leticia Marín-León 1

Bruna Fernanda do Nascimento Jacinto de Souza 1

Rafael Pérez-Escamilla 3

Ana Maria Segall-Corrêa 1

doi: 10.1590/0102-311X00247218
Correspondence

D. F. M. Camargo

Departamento de Saúde Coletiva, Faculdade de Ciências

Médicas, Universidade Estadual de Campinas.

Rua Tessália Vieira de Camargo 126, Campinas, SP

13083-887, Brasil.

danieleflaviane@hotmail.com

1 Faculdade de Ciências Médicas, Universidade Estadual de Campinas, Campinas, Brasil.

2 University of Alberta, Edmonton, Canada.

3 University of Yale, New Haven, U.S.A. 


\section{Introduction}

The overweight and obesity epidemics is a global phenomenon with growing prevalence in developed and developing countries 1. Excess weight is a concern, given its association with chronic diseases, such as diabetes, myocardial infarction, osteoarthritis, and neoplasms 1,2. In Brazil, a recent national telephone-based survey revealed $52.5 \%$ of the adults are overweight or obese 2. Estimates for 2050 show growing rates of nearly $70 \%$, which will impose an even greater health and economic burden to the Brazilian government 3.

As source of micronutrients, fibers, proteins, and antioxidants, a diet based on natural or minimally processed foods (e.g., fish, eggs, or other types of meat, legumes, wholegrains, fruits, and vegetables) is one of the strategies to prevent and control obesity and associated chronic diseases 4 . Despite the health benefits of a healthy diet, a low prevalence of natural or minimally processed food intake has been observed worldwide since the 1980 s 4,5. For instance, in Brazil, only $24.1 \%$ of the total population consume five daily servings of fruits and vegetables 6 , which is the recommendation of the World Health Organization (WHO) 7 and the Brazilian Ministry of Health 8 .

Socioecological models of healthy behaviors suggest the influence of environmental factors (e.g., availability and accessibility to retail outlets selling healthy foods) on the adoption and maintenance of healthy diet 9,10. Observational studies have described the associations between food environment and diet, suggesting a higher fruit and vegetable intake 6,11 and a low prevalence of excess weight 12 in areas with more food retails selling healthy foods. However, literature reviews have shown that this association is still inconclusive 9,13 and more studies are required. Furthermore, most of the investigations have focused on Anglo-saxon countries 14,15, where the characteristics of food environments and eating practices (e.g., higher consumption of ready-to-consume foods as well as lower costs of foods in fast-foods restaurant chains) are distinct from those of Latin-American countries 16 . Such differences may limit the generalization of the findings for other contexts and populations 6 .

Despite the increasing literature, few studies have analyzed the Brazilian food environment 14; see, for example, Duran et al. 6 and Jaime et al. 12. Thus far, Brazilian studies have found unhealthy food environments in neighborhoods with low income and education levels. For instance, a recent study found local grocery stores that usually have less availability of healthy foods are more prevalent in low than in high socioeconomic status neighborhoods in São Paulo city 6 . An in-depth understanding of the food environment in different socioeconomically disadvantaged areas in Brazil is still missing. This study helps fill this literature gap, by comparing the availability of food retail outlets and the adult residents' food shopping behaviors between low-income areas with low and high obesity prevalence in a big industrial Brazilian city.

\section{Methods}

This study uses data from a larger project on food insecurity and chronic diseases among adults, which was carried out in the urban area of the southeast Brazilian city of Campinas, São Paulo State, Brazil. With a population of over one million people 17 , Campinas is the third most populous city in the state of São Paulo. The larger project was a population-based cross-sectional study that collected anthropometric measures and data on food shopping behaviors. In addition to using data from the aforementioned survey, this study carried out a descriptive ecological survey, which obtained local food environment data through the mapping of food outlets followed by an in-store audit.

\section{Data collection}

Between 2011 and 2012, the survey was conducted in three of the municipal healthcare districts: South, Southwest, and Northwest. For administration purposes, the city of Campinas is divided into five healthcare districts, which are comprised of census tracts. To estimate the sample size for the survey, we considered a maximum variability for the frequency of the events $(\mathrm{P}=0.50), 95 \%$ confidence interval (95\%CI, $\mathrm{z}=1.96), 10 \%$ point sampling errors, and a design effect of 2.5 . The total sample size was 720 households ( 240 households in each of the three healthcare districts). 
Ten census tracts of each healthcare district were randomly selected. After drafting a list of all homes addresses in each census tract in the field survey, we identified a total of 6,349 households. We then randomly selected 938 households. With a loss of 3.6\% in relation to the sample calculated, the larger project included 694 households in total.

Twelve graduate students trained on health-related fields interviewed 694 people aged 18 years or over. The survey included the following sociodemographic variables: sex, age $(<35 ; 35-59 ; \geq 60)$, education of the household head and the interviewee based on schooling years $(<8 ; \geq 8)$; interviewee's self-reported race/color (white; nonwhite); per capita monthly household income ( $\leq 1$ minimum wage [MW]; > 1 MW, in which MW was equivalent to BRL 545,00 [USD 337.90] in 2011 and BRL 622,00 [USD 267.05] in 2012); and number of people living in the household $(1 ; 2-4 ; \geq 5)$. For the food environment, the questions included were: (1) the most frequently visited outlet for food purchase (hypermarkets, supermarkets, local grocery stores, stores specialized in selling fruit and vegetables, farmer's markets, snack bars, and bars); and (2) the monthly purchase of soft drinks (in liter), sugar (in kilo), margarine (500g pot), and vegetable oil ( $900 \mathrm{~mL}$ bottle) - which are common indicators of food consumption in Brazil. Interviewees' body weight and height were taken using accurately calibrated equipment and standardized procedures 18 .

In this study, we classified the ten census tracts selected of each healthcare district according to the obesity prevalence (i.e., body mass index $-\mathrm{BMI} \geq 30 \mathrm{~kg} / \mathrm{m}^{2}$ ) ${ }^{19}$. To do that, we used the interviewees' body weight and height collected in the larger project. The obesity levels in the census tracts varied from $17.6 \%$ to $52.9 \%$. Given that this study aimed to better capture the magnitude of social inequalities in food environment, we performed some exploratory data analyses to better group the areas. Based on the aforementioned local prevalence of obesity, we then determined that census tracts with obesity prevalence lower than $25 \%$ or higher than $45 \%$ would define areas with low and high obesity levels, respectively. These cutoff points resulted in the identification of 12 census tracts, which were grouped into clusters according to the obesity prevalence and geographic proximity.

Using the software AutoCAD (https://www.autodesk.com.br/products/autocad/free-trial), the clusters were defined by a radius of 500 meters $(\mathrm{m}) 20$ from the epicenter of census tracts. This cutoff point was chosen for better representing the transportation walking to utilitarian destinations 21. The area of the clusters with no adjacent census tracts was defined as $700 \mathrm{~m}^{2}$. For the adjacent census tracts, the cluster had a polygon shape obtained from the overlap of circles of each census tract; the average area was $1.6 \mathrm{~km}^{2}$. We obtained six clusters: two clusters with low obesity prevalence, two clusters with high obesity prevalence, and two clusters with mixed low and high obesity prevalence. The latter was excluded from this study to better measure the social inequalities between the extreme groups. In total, six census tracts were included. In the clusters identified with low and high obesity levels, a total of 155 people had been interviewed in the larger project.

Between July and December 2014, a trained researcher conducted a mapping of the food retail outlets located in the four clusters, by driving down every street of each cluster. The retail outlets were then classified by type of food store according to the name on the building facades (e.g., hypermarkets, supermarkets, local grocery stores, stores specialized in selling fruit and vegetables, bars, dessert or ice cream shops, pizza restaurants and other fried high-fat foods - e.g., deep-fried pasties and french fries). Later, the same researcher visited each food retail outlet to confirm the type of store previously recorded. An audit of the type of food sold was performed to ensure the correction of the classification done through mapping 22 .

\section{Data analysis}

Using the New Food Classification (2016) 4, the food retail outlets were grouped into: (a) natural or minimally processed foods; and (b) processed or ultra-processed foods. A third group was added to that classification; food outlets selling fruits and vegetables were considered a separate category given our interest in teasing out its consumption. This group encompassed supermarkets, local grocery stores, stores specialized in selling fruit and vegetables, kiosks selling fresh coconut water, and farmer's markets. The natural or minimally processed food group included butcher shop, sit-down restaurants, bakeries, and kiosks selling sugarcane juices and savory snacks. Finally, the processed and ultra-processed food group comprised bars, beverage warehouses, sandwich places, dessert and 
ice cream shops, pizza restaurants, fast-food shops selling savory snacks (e.g., deep-fried pasties), and baked potato shops. When natural and minimally processed foods and processed and ultra-processed foods were sold alongside, the food retail outlet was classified as the later. We attributed one point to each food retail outlet, independently of the type. An indicator of outlets by 1,000 persons residing in the each area was calculated using the sum of the respective outlets divided by the total population in each area, then divided by 1,000, where the higher the indicator the greater the number of outlets.

We used chi-square, Fisher's exact test, and t-tests to compare areas with low and high obesity prevalence. Using logistic regression, we calculated the odds ratio (95\%CI) adjusted for education. Income was not included in the adjusted analyses because the socioeconomic status was similar between clusters with low and high obesity prevalence (areas with low prevalence: 95\%CI: BRL 475.00-BRL 736.00 [USD 232.75-USD 360.64]; areas with high prevalence: 95\%CI: BRL 418.00-BRL 582.00 [USD 204.82-USD 285.18]; t-test p-value: 0.174). SPSS 18 (https://www.ibm.com/) was used to perform data analysis. All interviewees signed an informed consent form before participation. Both the aforementioned survey and this project obtained approval from the Health Research Ethics Board of State University of Campinas (Campinas).

\section{Results}

Out of 150 food retail outlets identified across the four clusters from the initial mapping, 27 establishments were supposed to sell fruits and vegetables. However, during the in-store audit, only 18 food retail outlets had fruits and vegetables available for purchase at the moment of visit, which represent only $12 \%$ of the total establishments. The most common places selling fruits and vegetables were local grocery stores (66.7\%) and supermarkets (22.2\%). Most of the outlets where fruits and vegetables were not available for purchase were bars (44.7\%) and sandwich places (10.6\%) Approximately 56\% of food retail outlets selling fruits and vegetables were present in the areas with high prevalence of obesity. Concerning the geographical distribution of the overall food retail outlets, $70 \%$ of them were located in the areas with low prevalence of obesity (Table 1).

More supermarkets, beverage warehouses, and bars were found in the areas with low prevalence of obesity than in the areas with high prevalence of obesity. Local grocery stores and stores specialized in selling fruits and vegetables were more prevalent in the latter. The indicators of food retail outlets selling processed and ultra-processed foods or with no availability of fruits and vegetables were higher in the areas with low prevalence of obesity. In contrast, the indicator of establishments selling fruits and vegetables was higher in the areas with high prevalence of obesity (Table 2).

Regarding sociodemographic characteristics of survey participants, no statistical differences were found between the two areas, except for education. The proportion of both interviewees and household heads with less than eight years of schooling was higher in the areas with high prevalence of obesity than in areas with low prevalence of obesity (Table 3). In both areas, the most common outlets where participants purchased food were local grocery stores. Compared with the residents living in the areas with low prevalence of obesity, the ones living in the areas with high prevalence of obesity were 2.9 times and 3.4 times more likely to purchase food in hypermarkets and stores specialized in selling fruit and vegetables, respectively (Table 4).

Table 5 shows that participants living in the areas with high prevalence of obesity reported consuming more soda drinks than their counterparts living in the areas with low obesity prevalence. No statistical difference between the two areas was found regarding the purchase of sugar, margarine, and oil.

\section{Discussion}

This study examined the food environment of a large industrial city in Brazil, exploring the differences in the availability of the food retail outlets and (un)healthy food items between low-income areas of different levels of obesity. The study also compared the adult residents' food shopping behaviors in these two areas. Thus far, a growing number of Brazilian studies have compared low and high socioeconomic status neighborhoods regarding food environment (see, for instance, Duran et al. 6). 
Table 1

Food outlets in areas with low and high obesity prevalence. Campinas, São Paulo State, Brazil, 2014.

\begin{tabular}{|c|c|c|c|c|c|c|}
\hline \multirow[b]{2}{*}{ Total population } & \multicolumn{2}{|c|}{$\begin{array}{c}\text { Areas with high } \\
\text { prevalence of obesity }\end{array}$} & \multicolumn{2}{|c|}{$\begin{array}{c}\text { Areas with low } \\
\text { prevalence of obesity }\end{array}$} & \multicolumn{2}{|c|}{ Total } \\
\hline & \multicolumn{2}{|c|}{1,340} & \multicolumn{2}{|c|}{1,740} & \multicolumn{2}{|c|}{3,080} \\
\hline Area in $\mathrm{km}^{2}$ & \multicolumn{2}{|c|}{$2,099.805$} & \multicolumn{2}{|c|}{$2,390.553$} & \multicolumn{2}{|c|}{$4,490.358$} \\
\hline Food outlets & $\mathbf{n}$ & $\%$ & $\mathbf{n}$ & $\%$ & $\mathbf{n}$ & $\%$ \\
\hline \multicolumn{7}{|l|}{ Availability of fruits and vegetables } \\
\hline Supermarkets & 1 & 10.0 & 3 & 37.5 & 4 & 22.2 \\
\hline Local grocery stores & 8 & 80.0 & 4 & 50.0 & 12 & 66.7 \\
\hline Stores specialized in selling fruit and vegetables & 1 & 10.0 & 0 & 0.0 & 1 & 5.6 \\
\hline Kiosks selling fresh coconut water & 0 & 0.0 & 1 & 12.5 & 1 & 5.6 \\
\hline Subtotal & 10 & 100.0 & 8 & 100.0 & 18 & 100.0 \\
\hline \multicolumn{7}{|l|}{ No availability of fruits and vegetables } \\
\hline Butcher shop & 4 & 11.4 & 2 & 2.1 & 6 & 4.5 \\
\hline Bars & 13 & 37.4 & 46 & 47.4 & 59 & 44.7 \\
\hline Beverage warehouses & 3 & 8.6 & 8 & 8.2 & 11 & 8.3 \\
\hline Bakeries & 6 & 17.1 & 3 & 3.1 & 9 & 6.8 \\
\hline Sit-down restaurants & 2 & 5.7 & 7 & 7.2 & 9 & 6.8 \\
\hline Baked potato shops & 0 & 0.0 & 1 & 1.0 & 1 & 0.8 \\
\hline Kiosks selling sugar cane juice and savoury snacks & 0 & 0.0 & 2 & 2.1 & 2 & 1.5 \\
\hline Sandwich places & 2 & 5.7 & 12 & 12.4 & 14 & 10.6 \\
\hline Fast-food shops selling savoury snacks (e.g., deep-fried pasties) & 0 & 0.0 & 6 & 6.2 & 6 & 4.5 \\
\hline Pizza restaurants & 3 & 8.6 & 3 & 3.1 & 6 & 4.5 \\
\hline Dessert and ice cream shops & 2 & 5.7 & 7 & 7.2 & 9 & 6.8 \\
\hline Subtotal & 35 & 100.0 & 97 & 0.0 & 132 & 100.0 \\
\hline Total & 45 & & 105 & & 150 & \\
\hline
\end{tabular}

Our investigation adds to this literature by examining the differences in two low-income areas, one with high and other low obesity prevalence. Our findings are many and important for a better understanding of the Brazilian food environment in socioeconomically deprived areas.

Despite the relative quantity and variety of food environments in both areas, few food retail outlets sold fruits and vegetables, representing only $12 \%$ of the total establishments identified. That is especially of concern considering approximately 5,013 people (the total population of both areas) 17 were living in areas with low availability of outlets selling fruits and vegetables. In addition, this result suggests remote mapping of food stores using street view services in a 360-degree panorama (e.g., Google Street View) are likely to overestimate the availability of fruits and vegetables in Brazil. That is, the quantity and variety of food retail outlets in the area may not mean more availability of fruits and vegetables. Therefore, despite costly, in-store audits are needed to better portray the local food environment.

The most prevalent outlets selling fruits and vegetables in both areas were local grocery stores, followed by supermarkets. We found supermarkets were more frequent in areas with low obesity prevalence. That is an important finding given supermarket chains usually sell fruits and vegetables at low price throughout the year and have weekly sales of fresh products. Conversely, local grocery stores and stores specialized in selling fruit and vegetables tend to not have special sales and its prices are higher than those of supermarkets ${ }^{6}$. Those retail outlets were more frequent in the areas with high obesity levels.

An important finding of our study is the socio-spatial distribution of food outlets selling processed and ultra-processed foods, which are considered indicators of unhealthy diet 2,23. While the lit- 


\section{Table 2}

Indicator of outlets classifying types of food outlets, according to the obesity prevalence in the area of residence. Campinas, São Paulo State, Brazil, 2014

\begin{tabular}{|c|c|c|}
\hline & $\begin{array}{l}\text { Areas with high prevalence } \\
\text { of obesity }\end{array}$ & $\begin{array}{c}\text { Areas with low prevalence } \\
\text { of obesity }\end{array}$ \\
\hline Total population & 1,340 & 1,740 \\
\hline Total number of outlets & 45 & 105 \\
\hline Type of food outlets & Food outlet/population & Food outlet/population \\
\hline Supermarkets & 0.75 & 1.72 \\
\hline Local grocery stores & 5.97 & 2.30 \\
\hline Stores specialized in selling fruit and vegetables & 0.75 & 0.00 \\
\hline Kiosks selling fresh coconut water & 0.00 & 0.57 \\
\hline Total availability of fruits and vegetables * & 7.46 & 4.60 \\
\hline Bars & 9.70 & 26.44 \\
\hline Beverage warehouses & 2.24 & 4.60 \\
\hline Total not availability of fruits and vegetables ** & 26.12 & 55.75 \\
\hline Total availability of natural or minimally processed foods *** & 8.96 & 8.05 \\
\hline Total availability of processed or ultra-processed foods\# & 17.16 & 47.70 \\
\hline
\end{tabular}

Note: independently of the type, each outlet was attributed one point and the sum was divided by the total number of persons in each area, divided by 1,000 .

* Supermarkets, local grocery stores, stores specialized in selling fruit and vegetables, and kiosks selling fresh coconut water;

** All food outlets except those selling fruits and vegetables;

*** Butcher shop, bakeries, sit-down restaurants, and kiosks selling sugar cane juice;

\# Sandwich places, fast-food shops selling savoury snacks, dessert and ice cream shops, pizza restaurants, bars, baked potato shops.

erature has shown more availability of processed and ultra-processed foods at lower price in deprived neighborhoods relative to affluent ones 12,24 , our study revealed differences within low-income areas. Although the food environment was less diverse in the areas of high obesity prevalence, the number of retail outlets selling fruits and vegetables was higher. In contrast, outlets selling processed and ultra-processed foods were more prevalent in the areas of low obesity prevalence. These findings are interesting because one can expect that areas of low obesity prevalence are more conducive to healthy eating than areas of high obesity prevalence. Three factors can help explain this unexpected result. First, the higher availability of fruits and vegetables in local specialized markets and supermarkets at potentially relative low prices does not translate into higher consumption of healthy foods and lower obesity rates. Second, these food retail outlets also sell unhealthy foods, such as potato chips, puffed cornmeal snacks, and sugary drinks. That may have some implications on food shopping decision. Third, as discussed in recent literature 14,25,26 and shown in socioecological frameworks 26,27, not only built environmental factors, but also economic and social factors shape food shopping and eating behaviors. Therefore, our study reinforces the importance of understanding food behaviors and health problems associated with diet 23,28 as results of a myriad of environmental and nonenvironmental factors.

Regarding outlets where people do their grocery shopping, we found residents of high obesity prevalence areas were more likely to go to supermarkets and specialized stores selling fruits and vegetables than their counterparts in the low obesity prevalence areas. Across both areas, hypermarkets seconded local grocery stores as popular retail outlets for grocery shopping; however, they were not found in the $500 \mathrm{~m}$ radius in the areas studied. A plausible reason for people buying their groceries further than their immediate surroundings is the greater variety of goods and the lower prices and sales offered by hypermarkets. It may also suggest transportation may not be a barrier for grocery 
Table 3

Demographic and socioeconomic characteristics of the household, household head, and interviewee, according to the obesity prevalence in the area of residence. Campinas, São Paulo State, Brazil, 2012.

\begin{tabular}{|c|c|c|c|c|c|}
\hline \multirow[t]{2}{*}{ Variables } & \multicolumn{2}{|c|}{ Areas with high prevalence of obesity } & \multicolumn{2}{|c|}{ Areas with low prevalence of obesity } & \multirow[t]{2}{*}{ p-value } \\
\hline & n & $\%$ & $\mathrm{n}$ & $\%$ & \\
\hline \multicolumn{6}{|l|}{ Household head } \\
\hline Gender * & & & & & 0.577 \\
\hline Female & 22 & 40.7 & 31 & 36.0 & \\
\hline Male & 32 & 59.3 & 55 & 64.0 & \\
\hline Age (years) * & & & & & 0.251 \\
\hline$<35$ & 6 & 11.1 & 17 & 19.8 & \\
\hline $35-59$ & 30 & 55.6 & 49 & 57.0 & \\
\hline$\geq 60$ & 18 & 33.3 & 20 & 23.3 & \\
\hline Education level (years) * & & & & & 0.023 \\
\hline$<8$ & 30 & 55.6 & 31 & 36.0 & \\
\hline$\geq 8$ & 24 & 44.4 & 55 & 64.0 & \\
\hline \multicolumn{6}{|l|}{ Interviewee } \\
\hline Gender & & & & & 0.720 \\
\hline Female & 34 & 58.6 & 54 & 55.7 & \\
\hline Male & 24 & 41.4 & 43 & 44.3 & \\
\hline Age (years) & & & & & 0.406 \\
\hline$<35$ & 17 & 29.3 & 36 & 37.1 & \\
\hline $35-59$ & 24 & 41.4 & 41 & 42.3 & \\
\hline$\geq 60$ & 17 & 29.3 & 20 & 20.6 & \\
\hline Education level (years) & & & & & 0.017 \\
\hline$<8$ & 25 & 43.1 & 24 & 24.7 & \\
\hline$\geq 8$ & 33 & 56.9 & 73 & 75.3 & \\
\hline Race/skin color & & & & & 0.456 \\
\hline White & 37 & 63.8 & 56 & 57.7 & \\
\hline Nonwhite & 21 & 36.2 & 41 & 42.3 & \\
\hline \multicolumn{6}{|l|}{ Household characteristics } \\
\hline Per capita household income (MW) $* *, \star \star *$ & & & & & 152 \\
\hline$<1$ & 42 & 72.4 & 63 & 71.6 & \\
\hline$\geq 1$ & 16 & 27.6 & 25 & 28.4 & \\
\hline Household size & & & & & 0.135 \\
\hline Alone & 6 & 10.3 & 21 & 21.6 & \\
\hline 2-4 people & 43 & 74.1 & 67 & 69.1 & \\
\hline 5 people or more & 9 & 15.5 & 9 & 9.3 & \\
\hline
\end{tabular}

* 15 with missing information;

** 9 with missing information;

*** MW: minimum wage, in 2012 = BRL 622.00 (USD 267.05).

shopping, as found elsewhere regarding the purchase of fruits and vegetables 29 . More variety, affordability, and individual taste preferences may be more decisive in food shopping than accessibility to food retail outlets 11,30 . Such findings indicate the complex environmental relationships shaping eating behaviors and obesity levels.

No differences between the two areas were found in terms of food shopping, except for the soft drink purchase. The residents of high obesity prevalence areas reported buying six liters of soft drink more than their counterparts in the low obesity prevalence areas. While estimates point out a more than 200\% increase in the soft drink consumption in Brazil between the 1980s and the 2000s 31, our 


\section{Table 4}

Most frequently visited food outlet for food purchase, according to the obesity prevalence in the area of residence. Campinas, São Paulo State, Brazil, 2012

\begin{tabular}{|c|c|c|c|c|c|c|c|c|c|}
\hline \multirow[t]{2}{*}{ Food outlets } & \multicolumn{2}{|c|}{$\begin{array}{l}\text { Areas with high } \\
\text { prevalence of } \\
\text { obesity }\end{array}$} & \multicolumn{2}{|c|}{$\begin{array}{c}\text { Areas } \\
\text { with low } \\
\text { prevalence of } \\
\text { obesity }\end{array}$} & \multirow[t]{2}{*}{$p$-value } & \multirow[t]{2}{*}{ OR $(95 \% \mathrm{CI})$} & \multirow[t]{2}{*}{ p-value } & \multirow[t]{2}{*}{ AOR $(95 \% \mathrm{Cl})$ * } & \multirow[t]{2}{*}{ p-value } \\
\hline & $\mathbf{n}$ & $\%$ & $\mathbf{n}$ & $\%$ & & & & & \\
\hline Hypermarkets & & & & & $0.008 * *$ & & 0.009 & & 0.007 \\
\hline Yes & 43 & 74.1 & 51 & 52.6 & & $2.58(1.27-5.26)$ & & $2.93(1.34-6.36)$ & \\
\hline No & 15 & 25.9 & 46 & 47.4 & & 1.00 & & 1.00 & \\
\hline Local grocery stores & & & & & $0.288 * *$ & & 0.292 & & 0.155 \\
\hline Yes & 52 & 89.7 & 81 & 83.5 & & 1.00 & & 1.00 & \\
\hline No & 6 & 10.3 & 16 & 16.5 & & $1.71(0.62-4.65)$ & & $2.23(0.73-6.79)$ & \\
\hline $\begin{array}{l}\text { Stores specialized in selling fruits and } \\
\text { vegetables }\end{array}$ & & & & & $<0.001 \star \star *$ & & $<0.001$ & & 0.001 \\
\hline Yes & 37 & 63.8 & 31 & 32.0 & & $3.75(1.89-7.44)$ & & $3.40(1.60-7.19)$ & \\
\hline No & 21 & 36.2 & 66 & 68.0 & & 1.00 & & 1.00 & \\
\hline Farmers' markets & & & & & $0.197 * * *$ & & 0.154 & & 0.289 \\
\hline Yes & 4 & 6.9 & 2 & 2.1 & & $3.51(0.62-19.84)$ & & $2.66(0.46-16.2)$ & \\
\hline No & 54 & 93.1 & 95 & 97.9 & & 1.00 & & 1.00 & \\
\hline Bars/Sandwich places & & & & & $0.677 * \star$ & & 0.678 & & 0.757 \\
\hline Yes & 7 & 12.1 & 14 & 14.4 & & 1.00 & & 1.00 & \\
\hline No & 51. & 87.9 & 83 & 85.6 & & $1.22(0.46-3.24)$ & & $1.18(0.40-3.52)$ & \\
\hline
\end{tabular}

Note: binary logistic regression.

OR: odds ratio; AOR: adjusted odds ratio; 95\% Cl: 95\% confidence interval.

*Adjusted for education level:

** Chi-square;

*** Fisher exact test.

Table 5

Self-reported monthly food purchase, according to obesity prevalence in the area of residence. Campinas, São Paulo State, Brazil, 2012.

\begin{tabular}{lccc}
\hline Monthly food purchase & Areas with high prevalence of obesity & Areas with low prevalence of obesity & p-value * \\
\hline Soft drinks (liters) & 17.4 & 11.0 & 0.039 \\
Sugar (kilos) & 3.9 & 4.0 & 0.921 \\
Margarine (500 grams container) & 1.7 & 1.4 & 0.096 \\
Vegetable oil (liters) & 3.2 & 3.0 & 0.600 \\
\hline
\end{tabular}

* t-Student test.

study suggests some socioeconomic groups may be at a higher risk of being overweight and developing chronic diseases 24,32,33 given their greater purchase of these beverages. The greater purchase of soft drink in the high obesity prevalence aresa is an interesting finding because, while the food environment was less diverse, more outlets selling fruits and vegetables were found in that area. A plausible explanation for that may be residents' education in both areas. Our study showed a higher proportion of less educated people living in the high obesity prevalence area, which confirms the inverse association found between education and obesity in Brazil 34 . This finding could be explained 
by the association between lower levels of education and scarce nutritional knowledge; poor awareness regarding the health benefits of a healthy, balanced diet and eating practices; and less successful adherence to recommended dietary guidelines ${ }^{10}$. As such, compared with their counterparts with higher educational background, people with fewer years of schooling may be less likely to adopt and maintain healthy eating habits regardless of the quality of the food environments in their neighborhoods. Another additional explanation would be the lower purchasing power of people with lower education, which may lead to the consumption of cheaper energy-dense foods instead of more healthy foods, such as fruits and vegetables 35,36 .

Some limitations of our study should be considered. First, this study used data from a crosssectional study. As such, no causal inference can be made given the temporal association between risk factors and health outcomes cannot be determined in this study design. Second, data from the mapping and in-store audit was collected three years later than the survey data. Although no studies describe how long it takes for significant changes in the food environments to occur, the food retail outlets found in 2014 possibly may not represent the food environment in 2011/2012. Third, a radius of 500 meters used here may not be the most appropriate to capture the space where people purchase food. Additionally, the food shopping behaviors and the associated distance travelled may differ depending on the type of food retail outlet. As no consensus is reached in the literature about the geographic distance to use in general 37 or for each type of retail, more studies are needed. While this study only helped to dissect the food environment, we recognize the public and private physical activity infrastructure (e.g., sidewalks, parks, and fitness centers) in the neighborhoods is another facet of the environmental contributions to the obesity levels.

Our study has many strengths. While most Brazilian studies on food environment examine the differences between low and high socioeconomic areas, our study compared two low-income areas with different obesity levels. It showed the heterogeneity of the poor areas regarding their respective food environment and shopping behaviors. Therefore, our data may help to design tailored health interventions on the individual and environmental scale for low-income areas that present low or high obesity prevalence. Another advantage is the inclusion of in-store audit as it precisely identified the availability of fruits and vegetables that otherwise would be misleading if only remote mapping was conducted. Last, the combination of mapping, in-store audit, and survey provided a rich dataset that better portrayed the environmental influences on people's food shopping.

\section{Conclusion}

Our study revealed differences in the food environment and people's food shopping behaviors in two low-income areas with high and low obesity prevalence. Unexpectedly, we found the areas with high obesity prevalence, although less diverse, can be characterized as more conducive to healthy eating given the higher number of food retail outlets selling fruits and vegetables. These findings suggest decision-makers, policy-makers, urban planners, and health authorities should step away from onefits-all type of health intervention and consider the plurality of food environments in socioeconomically disadvantaged areas. The development of healthy food access strategies for promotion of local healthy eating should address the geographic distribution of food retail outlets (particularly the ones selling fruits and vegetables) and ensure affordable healthy food options, particularly for low-income people. Examining the nuances in low-income areas with different obesity levels regarding food environment may help to better understand people's food shopping behaviors, and ultimately, diet and health outcomes in such neighborhoods. Investigations on knowledge, attitudes, and behaviors toward food shopping and consumption provide important information about sociocultural, educational, and economic barriers people face when trying to eat healthily. But, its findings can only partially explain people's food decisions. Our study points out the need for contextualizing such findings geographically to improve the understanding of the built environment where people's attitudes and behaviors are enacted. Combining mapping and in-store audit to determine the availability of food retail outlets and healthy food options may increase the likelihood for a successful health intervention. 


\section{Contributors}

D. F. M. Camargo contributed with conceptualization of the study and drafted the article. A. P. Belon contributed with the writing and review of the article. L. Marín-León contributed with the data analysis as well as with writing, and review of the article. B. F. N. J. Souza reviewed the final version of the article. R. Pérez-Escamilla contributed with the study design and data analysis, as well as reviewed the final version of the article. A. M. Segall-Corrêa contributed with the study design, data analysis, writing and review of the article.

\section{Additional informations}

ORCID: Daniele Flaviane Mendes Camargo ( 00000002-7535-217X); Ana Paula Belon (0000-00024600-3202); Leticia Marín-León (0000-0001-62141173); Bruna Fernanda do Nascimento Jacinto de Souza (0000-0003-0546-3429); Rafael Pérez-Escamilla (0000-0001-9416-8039); Ana Maria SegallCorrêa (0000-0003-0140-064X).

\section{Acknowledgments}

To São Paulo State Research Foundation (FAPESP), for the financial support.

\section{References}

1. World Health Organization. World health statistics 2011. http://www.who.int/whosis/ whostat/EN_WHS2011_Full.pdf (accessed on Jul/2017).

2. Departamento de Vigilância de Doenças e Agravos não Transmissíveis e Promoção da Saúde, Secretaria de Vigilância em Saúde, Ministério da Saúde. Vigitel Brasil 2014 saúde suplementar: vigilância de fatores de risco e proteção para doenças crônicas por inquérito telefônico. Brasília: Ministério da Saúde; 2015.

3. Rtveladze K, Marsh T, Webber L, Kilpi F, Levy D, Conde W, et al. Health and economic burden of obesity in Brazil. PLoS One 2013; 8:e68785.

4. Monteiro C, Cannon G, Levy R, Moubarac J-C, Jaime P, Martins AP, et al. NOVA: the star shines bright. World Nutrition 2016; 7:28-38.

5. Hall JN, Moore S, Harper SB, Lynch JW. Global variability in fruit and vegetable consumption. Am J Prev Med 2009; 36:402-9.

6. Duran AC, Diez Roux AV, Latorre MR, Jaime PC. Neighborhood socioeconomic characteristics and differences in the availability of healthy food stores and restaurants in São Paulo, Brazil Health Place 2013; 23:39-47.

7. World Health Organization; Food and Agriculture Organization of The United Nations. Diet, nutrition and the prevention of chronic diseases. Geneva: World Health Organization/Food and Agriculture Organization of The United Nations; 2002.

8. Ministério da Saúde. Guia alimentar para a população brasileira. Brasília: Ministério da Saúde; 2014.

9. Brug J, van Lenthe FJ, Kremers SP. Revisiting Kurt Lewin: how to gain insight into environmental correlates of obesogenic behaviors. Am J Prev Med 2006; 31:525-9.

10. Sallis JF, Glanz K. Physical activity and food environments: solutions to the obesity epidemic. Milbank Q 2009; 87:123-54.

11. Caspi CE, Kawachi I, Subramanian SV, Adamkiewicz G, Sorensen G. The relationship between diet and perceived and objective access to supermarkets among low-income housing residents. Soc Sci Med 2012; 75:1254-62.

12. Jaime PC, Duran AC, Sarti FM, Lock K. Investigating environmental determinants of diet, physical activity, and overweight among adults in São Paulo, Brazil. J Urban Health 2011; 88:567-81.

13. Kamphuis CB, Giskes K, Bruijn GJ, Wendel-Vos W, Brug J, van Lenthe FJ. Environmental determinants of fruit and vegetable consumption among adults: a systematic review. Br J Nutr 2006; 96:620-35.

14. Belon AP, Nykiforuk C. Possibilities and challenges for physical and social environment research in Brazil: a systematic literature review on health behaviors. Cad Saúde Pública 2013; 29:1955-73. 
15. Cummins S, Macintyre S. Food environments and obesity: neighbourhood or nation? Int J Epidemiol 2006; 35:100-4.

16. Moubarac JC, Claro RM, Baraldi LG, Levy RB, Martins AP, Cannon G, et al. International differences in cost and consumption of ready-toconsume food and drink products: United Kingdom and Brazil, 2008-2009. Glob Public Health 2013; 8:845-56.

17. Instituto Brasileiro de Geografia e Estatística. Sinopse por setores. http://www.censo2010.ibge. gov.br/sinopseporsetores (accessed on Jun/ 2016).

18. Instituto Brasileiro de Geografia e Estatística. Pesquisa de Orçamentos Familiares 2008-2009: despesas, rendimentos e condições de vida. https://biblioteca.ibge.gov.br/visualizacao/li vros/liv50063.pdf (accessed on 29/Aug/2015)

19. Associação Brasileira para o Estudo da Obesidade e da Síndrome Metabólica. Diretrizes brasileiras de obesidade 2016. http://www.abeso. org.br/uploads/downloads/92/57fccc403e5da. pdf (accessed on Nov/2016).

20. Hino AA, Reis RS, Sarmiento OL, Parra DC, Brownson RC. The built environment and recreational physical activity among adults in Curitiba, Brazil. Prev Med 2011; 52:419-22.

21. Kondo K, Lee JS, Kawakubo K, Kataoka Y, Asami Y, Mori K, et al. Association between daily physical activity and neighborhood environments. Environ Health Prev Med 2009; 14:196206.

22. Duran ACFL. Ambiente alimentar urbano em São Paulo, Brasil: avaliação, desigualdades e associação com consumo alimentar [Doctoral Dissertation]. São Paulo: Universidade de São Paulo; 2013

23. Duran AC, Lock K, Latorre MRDO, Jaime PC. Evaluating the use of in-store measures in retail food stores and restaurants in Brazil. Rev Saúde Pública 2015; 49:80.

24. Martins APB, Levy RB, Claro RM, Moubarac JC, Monteiro CA. Participação crescente de produtos ultraprocessados na dieta brasileira (1987-2009). Rev Saúde Pública 2013; 47:65665.

25. Duran AC, Jaime PC. Determinates ambientais da alimentação em saúde coletiva: avaliação e aplicações. In: Cardoso MA, organizador. Nutrição em saúde coletiva. São Paulo: Editora Atheneu; 2014. p. 31-7.

26. Swinburn BA, Sacks G, Hall KD, McPherson K, Finegood DT, Moodie ML, et al. The global obesity pandemic: shaped by global drivers and local environments. Lancet 2011; 378:804-14.
27. Glanz K, Sallis JF, Saelens BE, Frank LD. Healthy nutrition environments: concepts and measures. Am J Health Promot 2005; 19:3303.

28. Pessoa MC, Mendes LL, Gomes CS, Martins PA, Velasquez-Melendez G. Food environment and fruit and vegetable intake in a urban population: a multilevel analysis. BMC Public Health 2015; 15:1012.

29. Fuller D, Cummins S, Matthews SA. Does transportation mode modify associations between distance to food store, fruit and vegetable consumption, and BMI in low-income neighborhoods? Am J Clin Nutr 2013; 97:167-72.

30. Lytle LA, Sokol RL. Measures of the food environment: a systematic review of the field, 2007 2015. Health Place 2017; 44:18-34.

31. Monteiro CA, Levy RB, Claro RM, de Castro IRR, Cannon G. Increasing consumption of ultra-processed foods and likely impact on human health: evidence from Brazil. Public Health Nutr 2010; 14:5-13.

32. Levy RB, Claro RM, Bandoni DH, Mondini L, Monteiro CA. Disponibilidade de "açúcares de adição" no Brasil: distribuição, fontes alimentares e tendência temporal. Rev Bras Epidemiol 2012; 15:3-12.

33. Claro RM, Santos MAS, Oliveira TP, Pereira CA, Szwarcwald CL, Malta DC. Consumo de alimentos não saudáveis relacionados a doenças crônicas não transmissíveis no Brasil: Pesquisa Nacional de Saúde, 2013. Epidemiol Serv Saúde 2015; 24:257-65.

34. Monteiro CA, Conde WL, Popkin BM. Incomespecific trends in obesity in Brazil: 1975-2003. Am J Public Health 2007; 97:1808-12.

35. Jones-Smith JC, Karter AJ, Warton EM, Kelly M, Kersten E, Moffet HH, et al. Obesity and the food environment: income and ethnicity differences among people with diabetes: the diabetes study of Northern California (DISTANCE). Diabetes Care 2013; 36:2697-705.

36. Malta DC, Santos MAS, Andrade SS, Oliveira TP, Stopa SR, de Oliveira MM, et al. Tendência temporal dos indicadores de excesso de peso em adultos nas capitais brasileiras, 2006-2013. Ciênc Saúde Colet 2016; 21:1061-9.

37. Wilkins EL, Morris MA, Radley D, Griffiths C. Using geographic information systems to measure retail food environments: discussion of methodological considerations and proposed reporting checklist (Geo-FERN). Health Place 2017; 44:110-7. 


\section{Resumo}

Nosso estudo teve como objetivo comparar alguns aspectos do ambiente alimentar de duas áreas de baixa renda no município de Campinas, São Paulo, Brasil, sendo uma com baixa e a outra com alta prevalência de obesidade. Nós comparamos a disponibilidade de estabelecimentos comerciais vendendo alimentos, tipos de alimentos vendidos e hábitos alimentares dos residentes. Dados demográficos, socioeconômicos e de hábitos alimentares foram obtidos de um inquérito de saúde de base populacional. Também analisamos dados locais de ambiente alimentar coletados através de um mapeamento remoto dos estabelecimentos comerciais vendendo alimentos e auditoria dos alimentos vendidos. Para fins comparativos, as áreas foram selecionadas de acordo com a prevalência de obesidade (indice de massa corporal - IMC $\geq 30 \mathrm{~kg}$ / $\left.\mathrm{m}^{2}\right)$, definida como baixa $(<25 \%)$ e alta $(>45 \%)$. Dos 150 pontos de venda de produtos alimentares, apenas 18 vendiam frutas e vegetais em todas as áreas. Áreas com alta prevalência de obesidade tinham mais mercearias e lojas especializadas em frutas e vegetais, bem como maior número de comércios vendendo frutas e verduras. Com menor escolaridade, os residentes das áreas de prevalência alta de obesidade reportaram comprar alimentos mais frequentemente em hipermercados e lojas especializadas em frutas e vegetais, embora consumissem mais refrigerantes em comparação aos residentes das áreas de baixa prevalência. Nossos resultados sugerem que as intervenções em áreas carentes devem considerar os seus diversos contextos ambientais e a interação entre escolaridade $e$ comportamentos de compra de alimentos em ambientes menos propícios à alimentação saudável.

Obesidade; Meio Ambiente e Saúde Pública; Comportamento Alimentar; Alimentos

\section{Resumen}

El objetivo de nuestro estudio fue comparar algunos aspectos del entorno alimentario de dos áreas de baja renta en el municipio de Campinas, São Paulo, Brasil, existiendo en una baja y en otra alta prevalencia de obesidad. Comparamos la disponibilidad de establecimientos comerciales vendiendo alimentos, los tipos de alimentos vendidos, asi como los hábitos alimentarios de los residentes. Se obtuvieron datos demográficos, socioeconómicos y hábitos alimentarios de una encuesta de salud de base poblacional. También analizamos datos locales sobre el entorno alimentario, recogidos a través de un mapeo remoto de los establecimientos comerciales que vendian alimentos, así como una auditoría de los alimentos vendidos. Para fines comparativos, las áreas se seleccionaron de acuerdo con la prevalencia de obesidad (indice de masa corporal - IMC $\geq 30 \mathrm{~kg} / \mathrm{m}^{2}$ ), definida como baja (<25\%) y alta (> 45\%). De los 150 puntos de venta de productos alimenticios, solamente 18 vendian frutas y verduras en todas las áreas. Las áreas con alta prevalencia de obesidad tenían más tiendas de comestibles y tiendas especializadas en frutas $y$ verduras, así como un mayor número de comercios vendiendo frutas y verduras. Con menor escolaridad, los residentes de las áreas de prevalencia alta de obesidad informaron comprar alimentos más frecuentemente en hipermercados y tiendas especializadas en frutas y verduras, aunque consumieron más refrescos, en comparación con los residentes de las áreas de baja prevalencia. Nuestros resultados sugieren que las intervenciones en áreas de escasos recursos deben considerar sus diversos contextos ambientales y la interacción entre la escolaridad y los comportamientos de compra de alimentos en entornos menos propicios para la alimentación saludable.

Obesidad; Medio Ambiente y Salud Pública;

Conducta Alimentaria; Alimentos
Submitted on 20/Dec/2018

Final version resubmitted on 15/Mar/2019

Approved on 22/Mar/2019 